\title{
Penerapan Maqashid Syariah Index pada Perbankan Syariah di Indonesia
}

\section{Application of maqashid sharia index in sharia banking in Indonesia}

\section{Kristianingsih}

Jurusan Akuntansi, Politeknik Negeri Bandung

E-mail: kristianingsih@polban.ac.id

\section{R. Abidzar Al Fahri}

Program Studi D4 Keuangan Syariah, Politeknik Negeri Bandung

E-mail: rafahri@gmail.com

\section{Fiqi Fahri Al Malik}

Program Studi D4 Keuangan Syariah, Politeknik Negeri Bandung E-mail: fiqifahri96@gmail.com

\begin{abstract}
This study aims to analyze the performance of Islamic banking in Indonesia (case studies in) using the Maqashid Syariah Index (MSI) approach. This is a quantitative research with descriptive study approach with object of research being12 Islamic commercial banks, 4 banks in Indonesia as Bank Sharia BNI, Sharia BRI, Sharia Mandiri and Sharia BJB. The results showed that the performance of Islamic banking in Indonesia is considered better in the achievement of maqashid sharia.. The measurement results of the Maqasid Syariah Index show the highest ranking of Islamic banking in Indonesia is ranked 1st achieved by Bank Negara Indonesia Syariah with number 0.19138, the second ranking of Islamic banking in Indonesia is achieved by Bank BRI Syariah (BRIS) with 0.14879 and the three ranking of Islamic banking in Indonesian Bank Syariah Mandiri (BSM) was with 0.14580.
\end{abstract}

Keywords: financial performance, maqashid syariah, Islamic banking

\section{Pendahuluan}

Perbankan syariah saat ini mengalami pertumbuhan. Pertumbuhan ini tidak hanya terjadi di negara-negara yang mayoritas penduduknya beragama Islam (muslim), tetapi juga terjadi di beberapa negara yang mayoritas nonmuslim, misalnya United Kingdom (UK). Mereka berpendapat bahwa, pertumbuhan ini salah satunya disebabkan oleh perkembangan masyarakat pada abad ke21 yang mengarah kepada asalnya "back to basic", saat manusia pada umumnya memahami realitas Ilahi dan berbondong-bondong menuju Allah (Ariyanto, 2014:99). Dalam kondisi perekonomian yang sedang berkembang, sektor bank memiliki potensi dan peluang yang besar dalam peranannya yang merupakan suatu lembaga intermediasi keuangan (Setiawan et. al., 2020)

Hingga pada tahun 2018, industri keuangan Syariah global selalu mengalami pertumbuhan dari tahun tahun sebelumnya, walaupun dalam Perekonomian global pada tahun 2018 ditandai oleh pertumbuhan yang stabil. terlihat bahwa industri keuangan Syariah global menembus angkaUSD2,19 triliun pada tahun 2018. Menurut Islamic financial services industry (IFSI) bahwa pertumbuhan perbankan Syariah global tumbuh 71,7\% atau senilai USD1,57 triliun, Penerbitan sukuk tumbuh 24,2\% atau senilai USD 530 miliar, Adapun industri takāful global juga mencatat 
kenaikan 1,3\% atau senilai USD 61,5 miliar dan aset dana islam tumbuh 2,8\% atau senilai USD 27,7 miliar. Berikut statistik yang dikeluarkan oleh Islamic financial services industry pada bulan July 2019.

Tabel 1. Rincian Global IFSI menurut Sektor dan Wilayah (miliar dolar AS, 2018 *)

\begin{tabular}{|l|c|c|c|c|c|}
\hline \multicolumn{1}{|c|}{ Wilyah } & $\begin{array}{c}\text { Aset } \\
\text { Perbankan }\end{array}$ & Sukuk & $\begin{array}{c}\text { Aset Dana } \\
\text { Islam }\end{array}$ & Takaful & Total \\
\hline Asia & 266,1 & 323,2 & 24,2 & 4,1 & 617,6 \\
\hline GCC & 704,8 & 187,9 & 22,7 & 11,7 & 927,1 \\
\hline MENA (ex-GCC) & 540,2 & 0,3 & 0,1 & 10,3 & 550,9 \\
\hline Africa (ex-North) & 13,2 & 2,5 & 1,5 & 0,01 & 17,21 \\
\hline lainya & 47,1 & 16,5 & 13,1 & - & 76,7 \\
\hline Total & 1571,4 & 530,4 & 61,5 & 27,7 & 2190 \\
\hline
\end{tabular}

Sumber : IFSB, July 2019 (Data diolah Penulis)

Dapat dilihat dari gambar diatas tentunya ini adalah hal yang menggembirakan bagi industri keuangan syariah global, apalagi di sektor perbankan yang mendominasi secarakeseluruhan.

Dalam Global Islamic Financial Report (GIFR) 2019 terbaru, Indonesia mencatat skor 81.93 pada Islamic Finance Country Index (IFCI) 2019. Dengan skor tersebut, Indonesia berada di peringkat pertama dalam Pasar Keuangan Syariah Global setelah pada tahun lalu berada di peringkat keenam dengan skor 24.13, negara yang memiliki potensi dan kondusif dalam pengembangan industri keuangan syariah di lanjutkan dengan negara Malaysia, Iran, Saudi arabia, sudan, Brunei Darussalam dan UAE. Hal ini membuat Indonesia berhasil menyalip negara-negara anggota Gulf Cooperation Council (GCC) dan Malaysia yang selalu mendominasi peringkat teratas sejak 2011. Seperti yang disampaikan oleh Menteri Bappenas sekaligus Sekretaris KNKS Bambang Brodjonegoro, bahwa penghargaan tersebut merupakan bentuk pengakuan terhadap upaya pemerintah, pelaku usaha, akademisi, dan masyarakat dalam merealisasikan Masterplan Arsitektur Keuangan Syariah (MAKSI) dan Masterplan Ekonomi Syariah Indonesia (MEKSI) dalam rangka meningkatkan peran keuangan syariah dalam rencana strategis pembangunan ekonomi nasional. Sistem keuangan dapat pun menjadi motor penggerak perekonomian dengan cara memperbaiki berbagai kelemahan dan kendala yang dihadapi (Setiawan, 2017:173).

Tabel 2. Islamic Finance Country Index (IFCI) Ranks for 2014 - 2019

\begin{tabular}{|c|l|l|l|l|l|l|}
\hline Rank & \multicolumn{1}{|c|}{2014} & \multicolumn{1}{c|}{2015} & \multicolumn{1}{c|}{2016} & \multicolumn{1}{c|}{2017} & \multicolumn{1}{c|}{2018} & \multicolumn{1}{c|}{2019} \\
\hline 1 & Iran & Iran & Malaysia & Malaysia & Malaysia & Indonesia \\
\hline 2 & Malaysia & Malaysia & Iran & Iran & Iran & Malaysia \\
\hline 3 & $\begin{array}{l}\text { Saudi } \\
\text { Arabia }\end{array}$ & $\begin{array}{l}\text { Saudi } \\
\text { Arabia }\end{array}$ & $\begin{array}{l}\text { Saudi } \\
\text { Arabia }\end{array}$ & $\begin{array}{l}\text { Saudi } \\
\text { Arabia }\end{array}$ & $\begin{array}{l}\text { Saudi } \\
\text { Arabia }\end{array}$ & Iran \\
\hline 4 & Bahrain & UAE & UAE & UAE & UAE & Saudi Arabia \\
\hline 5 & Kuwait & Kuwait & Kuwait & Kuwait & Kuwait & Sudan \\
\hline 6 & UAE & Bahrain & Indonesia & Pakistan & Indonesia & $\begin{array}{l}\text { Brunei } \\
\text { Darussalam }\end{array}$ \\
\hline 7 & Indonesia & Indonesia & Qatar & Indonesia & Pakistan & UAE \\
\hline
\end{tabular}

Sumber : Global Islamic Financial Report (GIFR) 2019

Berkembangnya Perbankan Syariah secara global harusnya diimbangi dengan kinerja bank syariah dalam mewujudkan kepercayaan Stakeholder. Untuk mewujudkan kepercayaan tersebut maka dibutuhkan alat pengukuran kinerja pada perbankan syariah tersebut. Namun pengukuran 
kinerja perbankan syariah masih banyak yang menggunakan pengukuran rasio-rasio keuangan seperti, RGEC (Risk Profile, Good Corporate Governance, Earnings, Capital), EVA(Economic value Added) dan Profitabilitas. Apabila perbankan syariah hanya menggunakan pengukuran yang sama dengan perbankan konvensional untuk mengukur kinerjanya, akan terdapat nilai yang tidak sebanding dari penggunaan indikator kinerja perbankan konvensional dengan objek yang lebih luas yang terdapat pada perbankan syariah (Mohammed et al, 2008).

Atas dasar latar belakang tersebut penelitian ini memiliki fokus untuk melakukan analisis kinerja perbankan syariah dengan menggunakan Maqashid Syariah Index (MSI), pada perbankan syariah di Indonesia dengan mengambil sampel bank umum syariah.

\section{Kajian Pustaka}

Bank syariah merupakan salah satu lembaga keuangan syariah yang kegiatan usahanya sejalan dengan prinsip-prinsip dasar dalam ekonomi Islam. Tujuan ekonomi Islam bagi bank syariah tidak hanya berfokus pada tujuan komersil (profit oriented), tetapi juga mempertimbangkan perananya dalam memberikan kesejahteraan secara luas bagi masyarakat (maslabab). Kontribusi bank syariah untuk turut ikut serta dalam memberikan kesejahteraan masyarakat merupakan salah satu bentuk peranan bank syariah dalam melaksanakan fungsi sosialnya. Bank Syariah adalah bank yang menjalankan kegiatan usaha berdasarkan prinsip syariah, atau prinsip hukum Islam (Lestari et. al., 2020). Hal ini sangat berbeda dengan sistem keuangan konvensional yang memusatkan pada aspek transaksi dan ekonomi saja. Karakter yang dimiliki bank syariah memungkinkan pengukuran kinerja dari sisi lain yang khusus bagi bank syariah. Sehingga dapat diketahui kesesuaian kinerja perbankan syariah dengan tujuan syariah pada umumnya (maqashid syariah). Secara etimologi maqashid alsyari'ah terdiri dari dua kata, yakni maqashid dan syariah.

Maqashid adalah bentuk jamak dari maqshud yang berarti kesengajaan, atau tujuan. Adapun syari'ah artinya jalan menuju air, atau bisa dikatakan dengan jalan menuju ke arah sumber kehidupan. Dengan demikian, maqashid al-syari'ah dapat diartikan sebagai tujuan Allah sebagai shari' dalam menetapkan hukum yang terintegrasi terhadap hambanya. Inti dari maqashid alsyari'ah adalah untuk mewujudkan kebaikan sekaligus menghindarkan keburukan atau menarik manfaat (maslahah).

Maqasid al-Shari'ah framework adalah kerangka atau model pengukuran kinerja perbankan syariah yang sesuai dengan tujuan dan karakteristik perbankan syariah (Farihah \& Setiawan, 2020). Dalam penelitian ini, penulis menggunakan konsep tujuan syariah berdasarkan Abu Zahara (1997) seperti beberapa penelitian yang telah dilakukan sebelumnya. Menurut Abu Zahara (1997), secara spesifik perbankan syariah memiliki tiga tujuan utama yang harus dipenuhi, yaitu:

1) Tahdhib al-Fard (Pendidikan Individu)

Tujuan pertama tentang bagaimana seharusnya perbankan syariah menyebarkan pengetahuan dan kemampuan serta menanamkan nilai-nilai individu untuk perkembangan spiritualnya. Dengan demikian, bank syariah harus merancang program pendidikan dan pelatihan yang harus mengembangkan tenaga kerja yang berpengetahuan dan terampil dengan nilai-nilai moral yang tepat.

2) Iqamah al-'Adl (Pembentukan Keadilan)

Tujuan kedua yaitu perbankan syariah harusmeyakinkan bahwa setiap transaksi dalam aktivitas bisnis dilakukan secara adil termasuk produk, harga, ketentuan, dan kondisi kontrak. Selain itu perbankan syariah juga harus meyakinkan bahwa setiap bisnis perbankan bebas dari elemen- elemen negatif yang dapat menciptakan ketidakadilan seperti riba, kecurangan, dan korupsi. Secara tidaklangsung, bankharusbijakmenggunakankeuntungan dan mengarahkankegiatanke arah yang dapat membantu mengurangi ketidaksetaraan 
pendapatan dan kekayaan.

3) Jalb al-Maslahah (Kepentingan Publik)

Tujuan ketiga yaitu perbankan syariah harus membuat prioritas mengenai aktivitas bisnis mana yang memberikan manfaat yang lebih besar bagi masyarakat. Tujuan ini termasuk kegiatan yang mencakup kebutuhan dasar masyarkat seperti investasi di sektor-sektor vital, pembiayaan proyek perumahan, dan lain sebagainya.

Syariah Maqasid Index ini merupakan metode pengukuran kinerja perbankan syariah yang dirumuskan oleh Mustafa Omar Mohammed, Dzuljastri Abdul Razak dan Fauziah Md Taib (2008, 2015). Ketiga tujuan diatas oleh Mohammed et al (2008, 2015) diturunkan menjadi beberapa indikator pengukuran dengan menggunakan metode operasionalisasi Sekaran. Hal ini dilakukan agar ketiga tujuan syariah diatas dapat secara operasional diukur dan ditentukan nilainya. Dengan menggunakan metode Sekaran, penilaian kinerja perbankan syariah berdasarkan konsep Maqasid al-Shari'ah yang dirumuskan oleh para peneliti adalah sebagai berikut:

Tabel 3. Model Pengukuran Maqashid Syariah

\begin{tabular}{|c|c|c|c|c|c|}
\hline & Konsep & Dimensi & Elemen & Rasio Kinerja & Sumber \\
\hline & \multirow[t]{4}{*}{$\begin{array}{l}\text { Mendidik } \\
\text { Individu }\end{array}$} & \multirow[t]{2}{*}{$\begin{array}{l}\text { D1 (meningkatkan } \\
\text { pengetahuan) }\end{array}$} & $\begin{array}{l}\text { E1 (hibah } \\
\text { pendidikan) }\end{array}$ & $\begin{array}{l}\text { R1 (hibah } \\
\text { pendidikan/total biaya) }\end{array}$ & $\begin{array}{l}\text { Publikasi } \\
\text { Laporan } \\
\text { tahunan }\end{array}$ \\
\hline & & & E2 (penelitian) & $\begin{array}{l}\text { R2 (biaya penelitian/ } \\
\text { total biaya) }\end{array}$ & $\begin{array}{l}\text { Publikasi } \\
\text { Laporan } \\
\text { tahunan }\end{array}$ \\
\hline & & $\begin{array}{l}\text { D2 (menambah dan } \\
\text { meningkatkan } \\
\text { kemampuan } \\
\text { baru) } \\
\end{array}$ & E3 (pelatihan) & $\begin{array}{l}\text { R3 (biya pelatihan/total } \\
\text { biaya) }\end{array}$ & $\begin{array}{l}\text { Publikasi } \\
\text { Laporan } \\
\text { tahunan }\end{array}$ \\
\hline & & $\begin{array}{l}\text { D3 (menciptakan } \\
\text { kesadaran masyarakat } \\
\text { akanadanya perbankan } \\
\text { syariah) }\end{array}$ & E4 (publisitas) & $\begin{array}{l}\text { R4 (biaya } \\
\text { publisitas/total biaya) }\end{array}$ & $\begin{array}{l}\text { Publikasi } \\
\text { Laporan } \\
\text { tahunan }\end{array}$ \\
\hline & \multirow{3}{*}{$\begin{array}{l}\text { Mewujudka } \\
\text { n Keadilan }\end{array}$} & D4 (kontrak yang adil) & $\begin{array}{l}\text { E5 (pengembalian } \\
\text { yang adil) }\end{array}$ & $\begin{array}{l}\text { R5 (PER)/ total } \\
\text { investasi }\end{array}$ & $\begin{array}{l}\text { Publikasi } \\
\text { Laporan } \\
\text { tahunan }\end{array}$ \\
\hline & & $\begin{array}{l}\text { D5 (produk dan } \\
\text { layananterjangkau) }\end{array}$ & $\begin{array}{l}\text { E6 (biaya yang } \\
\text { terjangkau) }\end{array}$ & $\begin{array}{l}\text { R6 (mudharabah and } \\
\text { musyarkah / total } \\
\text { investasi) }\end{array}$ & $\begin{array}{l}\text { Publikasi } \\
\text { Laporan } \\
\text { tahunan }\end{array}$ \\
\hline & & $\begin{array}{l}\text { D6 (penghapusan } \\
\text { ketidakadilan) }\end{array}$ & $\begin{array}{l}\text { E7 (produk bank } \\
\text { non bunga) }\end{array}$ & $\begin{array}{l}\text { R7 (pendapatan non } \\
\text { bunga/total } \\
\text { pendapatan) }\end{array}$ & $\begin{array}{l}\text { Publikasi } \\
\text { Laporan } \\
\text { tahunan }\end{array}$ \\
\hline \multirow{2}{*}{\multicolumn{2}{|c|}{$\begin{array}{l}\text { 3) Kepentinga } \\
\mathrm{n} \\
\text { Masyarakat }\end{array}$}} & D7 (profitabilitas) & E8 (rasio laba) & $\begin{array}{l}\text { R8 (laba bersih/total } \\
\text { aktiva) }\end{array}$ & $\begin{array}{l}\text { Publikasi } \\
\text { Laporan } \\
\text { tahunan }\end{array}$ \\
\hline & & $\begin{array}{l}\text { D8 (pendistribusian } \\
\text { kekayaan \& laba) }\end{array}$ & $\begin{array}{l}\text { E9 (pendapatan } \\
\text { operasional) }\end{array}$ & R9 (zakat/laba bersih) & $\begin{array}{l}\text { Publikasi } \\
\text { Laporan } \\
\text { tahunan }\end{array}$ \\
\hline
\end{tabular}

Sumber: Mohammed et al (2015)

Berdasarkan landasan teori yang dijabarkan diatas, peneliti mencoba merumuskan kerangka dari penelitian berdasarkan teori mqashid syariah yang diadopsi dari Abu Zahrah. Kerangka teori dibawah ini menggambarkan konsep pengukuran kinerja perbankan syariah yang diturunkan dari 
teori maqashid syariah menggunakan metode operasionalisasi sekarang. Kerangka pemikiran yang objek nya yaitu Perbankan Syariah yang berada pada negara Indonesia yaitu BNI Syariah, BRI Syariah, Mandiri Syariahdan BJB Syariah untuk dikaji laporan keuangan perbankannya pada tahun 2015 hingga 2018 melalui penerapan Maqashid Syariah untuk dapat menilai Tahdzzib al-Fard (pendidikan individu), Iqamah al-Adl (mewujudkan keadilan) dan Jalb al- Maslahah (pencapaian kesejahteraan) di setiap bank yang ada di Negara tersebut.

\section{Metode Penelitian}

Penelitian ini merupakan penelitian kuantitatif dengan pendekatan studi deskriptif. Populasi yang digunakan dalam penelitian ini adalah Bank Umum Syariah di Indonesia yang terdaftar pada Islamic Finance Coutry Index. Teknik pengambilan sampel dalam penelitian ini dilakukan secara purposive sampling, adapun kriteria dalam pengambilansampel tersebut diantaranya:

1. Bank umum syariah pemerintah di Indonesia

2. Bank umum tersebut menerbitkan laporan keuangan selama 4 tahun berturut-turut yaitu pada tahun 2017-2020

3. Laporan keuangan yang dibuat (point2) memuat: Neraca,Laporan laba Rugi dan Laporan Rasio Keuangan.

Berdasarkan kriteria tersebut, sampel yang digunakan dalam penelitian ini adalah 4 bank umum Syariah di Indonesia yaitu BNI syariah, BRI Syariah, Mandiri Syariah dan BJB Syariah.

Metode pengukuran kinerja perbankan syariah yang digunakan dalam penelitian ini adalah metode yang digunakan oleh Mohammed et al, $(2008,2015)$ dalam bentuk Maqasid Syariah Index (MSI) yang diadopsi dari Abu Zahrah dalam konsep maqasid syariah.

Dalam penelitan Devi (2017) mengungkapkan bahwa terdapat tiga tahapan yang akan dilakukan untuk mengukur kinerja maqasid syariah pada bank Syariah.

\section{Hasil dan Pembahasan}

\subsection{Rasio kinerja Bank Syariah Berdasarkan Maqashidal-Shari'ah}

Tabel 4. Rasio Kinerja Maqasidal-Shari'ab Tujuan Pertama Perbankan Syariah Indonesia

\begin{tabular}{|c|c|c|c|c|}
\hline \multirow{2}{*}{ Bank } & \multicolumn{4}{|c|}{$\begin{array}{l}\text { Rasio Kinerja tujuan kesatu rasio rata rata (2017- } \\
\text { 2020) }\end{array}$} \\
\cline { 2 - 5 } & R11 & R21 & R31 & R41 \\
\hline BSM & 0,00957 & 0,00017 & 0,00957 & 0,01354 \\
\hline BRIS & 0,00407 & 0,00000 & 0,00407 & 0,01618 \\
\hline BNIS & $\mathbf{0 , 0 1 8 0 4}$ & 0,00000 & $\mathbf{0 , 0 1 8 0 4}$ & $\mathbf{0 , 0 4 0 4 9}$ \\
\hline BJBS & 0,00000 & $\mathbf{0 , 0 4 1 3 6}$ & 0,00000 & 0,00000 \\
\hline
\end{tabular}

\section{Rasio Kinerja Maqashid Syariah Tujuan Pertama (Tahdzib al-Fard) Indonesia, Malaysia dan Iran}

\section{Education Grant / Total Income (R11)}

Bank BNI Syariah (BNIS), dengan total hibah di bidang pendidikan mencapai 0,01804\% dengan diikuti oleh Bank Syariah Mandiri (BSM) mencapai 0,00957\%, Serta Bank Rakyat Indonesia Syariah mencapai 0,00407\%, Hal tersebut menunjukkan bahwa bank umum syariah di 
Indonesia memiliki kontribusi yang lebih besar. Dengan adanya biaya pendidikan yang disalurkan kepada masyarakat oleh bank umum syariah diharapkan dapat berperan dalam mengembangkan pengetahuan masyarakat karena Pendidikan bisa dikatakan sebagai salah satu kunci pembentukan sumber daya manusia yang berkualitas.

\section{Research Expense/Total Expense (R21)}

Rasio yang kedua yang menggambarkan pengeluaran dana yang digunakan untuk tujuan penelitian dan pengembangan terutama dalam pengembangan bank syariah itu sendiri. Dilihat pada tabel 5 di atas menunjukkan bahwa Bank Jabar Banten Syariah berada pada urutan pertama dalam bidang penelitian mencapai 0,04136 .

\section{Training Expense/Total Expense (R31)}

Rasio ketiga dalam rasio kinerja maqasid syariah index yang pertama adalah jumlah dana yang dikeluarkan oleh bank syariah untuk kegiatan pelatihan maupun pendidikan pada para karyawan perbankan syariah. Perbankan Syariah asal Indonesia yaitu Bank Negara Indonesia Syariah berada pada peringkat pertama untuk resio kinerja maqasid syariah index ketiga dapat dilihat dari table 5 di atas mencapai 0,01804\% dengan diikuti oleh Bank Syariah Mandiri mencapai 0,00957\%, Bank Rakyat Indonesia Syariah mencapai 0,00407\%.

\section{Publicity Expense/Total Expense (R41)}

Rasiopertama dalamrasio kinerjamaqasidsyariahindex yangkeempatdilihatdari table $5 \mathrm{di}$ atas adalah publisitas. Publisitas merupakan hal yangsangatpenting, karenatanpapublisitas atau promosi perbankan syariah akan lambat dalam mengalami pertumbuhan. Perbankan Syariah asal Indonesia yaitu Bank Negara Indonesia Syariah berada pada peringkat pertama untuk rasio kinerja maqasid syariah index keempat mencapai $0,04049 \%$ serta diikuti oleh Perbankan asal Negara Iran yaitu Saman Bank mencapai 0,03856\% dan diikuti oleh Perbankan asal Malaysia yaitu Bank Muamalat Malaysia Berhad mencapai 0,02061\%.

Tabel 5. Rasio Kinerja Maqasidal-Shari'ah Tujuan kedua (Iqamah al-Adl) Indonesia

\begin{tabular}{|c|c|}
\hline \multirow{2}{*}{ bank } & $\begin{array}{c}\text { RK tujuan kedua rasio rata rata } \\
(2015-2018)\end{array}$ \\
\cline { 2 - 2 } & R22 \\
\hline BSM & 0,30963 \\
\hline BRIS & 0,35337 \\
\hline BNIS & 0,22444 \\
\hline BJBS & 0,12413 \\
\hline
\end{tabular}

\section{Rasio Kinerja Maqasid al-Shari'ah Tujuan kedua (Iqamah al-Adl) Indonesia, Mudharabah And Musyarakah Modes/Total Investment Mode (R22)}

Rasio kedua dalam rasio kinerja maqasid syariah index yang kedua adalah functional distribution. Rasio kinerja maqasid syariah index yang kedua ini menggunakan pengukuran mudharabah and musyarakah modes, seberapa besar perbankan syariah di Indonesia mengunakan pembiayaan dengan sekema bagi hasil mudharabah dan musyarakah terhadap seluruh model pembiayaan yang diberikan bank syariah. Semakin tinggi model pembiayaan bank syariah menggunakan mudharabah dan musyarakah menunjukkan bahwa bank syariah tersebut meningkatkan fungsinya untuk menetapkan keadilan sosial ekonomi melalui transaksi bagi hasil. Pada elemen keenam ini Kafarin Bank yaitu bank syariah Iran, memiliki rasio paling tinggi sebesar 0,90993\% dari totalpembiayaan yangmenggunakan skim bagi hasil. Kemudian setelah Kafarin Bank diikuti oleh Parsian Bank asal Negara Iran pula dengan rasiosebesar 0,75497\% serta diikuti pulaoleh 
Saman Bankasal Negara Iranpula dengan rasio sebesar 0,68574\%.

Tabel 6. Rasio Kinerja Maqashid Syariah Tujuan Ketiga (Jalb al-Maslahah) Indonesia, Malaysia dan Iran

\begin{tabular}{|c|c|r|r|r|}
\hline \multirow{3}{*}{ negara } & \multirow{3}{*}{ bank } & \multicolumn{4}{|c|}{ RK tujuan ketiga rasio rata rata (2015-2018) } \\
\cline { 3 - 5 } & & R13 & R23 & R33 \\
\hline \multirow{3}{*}{ Indonesia } & BSM & 0,00464 & 0,00032 & 0,95362 \\
\cline { 2 - 5 } & BRIS & 0,00431 & 0,00023 & 0,93446 \\
\cline { 2 - 5 } & BNIS & 0,00967 & $\mathbf{0 , 5 9 9 5 4}$ & 0,96319 \\
\cline { 2 - 5 } & BJBS & $-0,02545$ & 0,03442 & 0,89594 \\
\hline
\end{tabular}

\section{Rasio Kinerja Maqashid Syariah Tujuan Ketiga (Jalb al-Maslahah) Indonesia,}

\section{Net Income/Total Asset (R13)}

Elemen kedelapan yang merupakan rasio laba yang menunjukkan kemampuan bank syariah untuk mengelola kekayaannya secara optimal dan bijaksana untuk memperoleh laba yang tinggi, pada elemen kedelapan ini dilihat pada table 7 Bank Jabar Banten Syariah asal Indonesia mengalami minus sebesar $-0,02545 \%$ dan juga sama hal nya dengan Tejarat Bank mengalami minus sebesar 0,01134\%. Laba bersih yang tinggi memungkinkan bank syariah berkontribusilebihterhadap anggaranpemerintah untuk proyek- proyek pembangunan dan untuk pelayanan sosial, serta dapat meningkatkan kesejahteraan masyarakat.

\section{Zakah Paid/Net Asset (R23)}

Rasio ketiga dalam rasio kinerja maqasid syariah index yang kedua adalah personal income. Perbankan syariah memiliki peran penting untuk mendistribusikan kekayaan kepada masyarakat lapisan bawah. Peran penting ini dapat dilakukan perbankan syariah melalui pendistribusikan dana zakat oleh perbankan syariah itu sendiri. Rasio paling tinggi pada elemen kesembilan ini terdapat pada Bank Negara Indonesia Syariah atau berada pada urutan pertama dengan rasio mencapai 0,59954\%, Ini berarti besarnya zakat yang dikeluarkan Bank Negara Indonesia Syariah setara dengan 0,59954\% dari laba bersihnya. Selanjutnya diikuti oleh bank Jabar Banten Syariah yang mana merupakan bank dari Negara Indonesia, zakat yang dikeluarkan setara dengan $0,03442 \%$ dari laba bersihnya.

\section{Investment In Real Econoic Sectors / Total Investment (R33)}

Elemen kesepuluh yaitu rasio investasi pada sektor riil yang digambarkan oleh investasi bank syariah pada sektor ekonomi riil dibandingkan dengan seluruh investasi bank syariah. Aktivitas investasi di sektor ekonomi riil memberikan dampak langsung yang positif kepada perekonomian masyarakat dibandingkan dengan aktivitas di sektor keuangan.

\subsection{Indikator kinerja Bank Syariah Berdasarkan Maqashid al-Shari'ah} Tujuan pertama: Pendidikan Individu (Tahdzib al-fard)

Tabel 7. Indikator Kinerja Maqasid al-Shari'ah Tujuan Pertama Periode 2017 - 2020

\begin{tabular}{|l|c|c|c|c|c|r|}
\hline \multirow{3}{*}{ Negara } & \multirow{3}{*}{ Bank } & \multicolumn{5}{|c|}{ IK untuk Tujuan pertama (2017-2020) } \\
\cline { 3 - 7 } & & IK 11 & IK21 & IK31 & IK41 & TOTAL1 \\
\hline & BSM & 0,00069 & 0,00001 & 0,00075 & 0,00093 & 0,00238 \\
\hline & BRIS & 0,00029 & 0,00000 & 0,00032 & 0,00112 & 0,00173 \\
\hline
\end{tabular}




\begin{tabular}{|l|c|r|r|r|r|r|}
\hline \multirow{2}{*}{$\begin{array}{l}\text { INDONESI } \\
\mathrm{A}\end{array}$} & BNIS & $\mathbf{0 , 0 0 1 3 0}$ & 0,00000 & $\mathbf{0 , 0 0 1 4 1}$ & $\mathbf{0 , 0 0 2 7 9}$ & $\mathbf{0 , 0 0 5 5 0}$ \\
\cline { 2 - 7 } & BJBS & 0,00000 & $\mathbf{0 , 0 0 3 3 5}$ & 0,00000 & 0,00000 & 0,00335 \\
\hline
\end{tabular}

Dapat diketahui bahwa secara keseluruhan BankNegara Indonesia Syariah (BNIS) asal Negara Indonesia lebih baik dalam mencapai tujuan pertama (Pendidikan individu) dibandingkan dengan bank syariah lainnya. Keunggulan Bank Negara Indonesia Syariah disebabkan dengan tingginya pengalokasian dana yang dilakukan oleh perbankan syariah tersebut untuk bidang pendidikan (sebesar 0,00130), pelatihan (sebesar 0,0141) dan publisitas (sebesar 0,0279) dengan total indikator kinerja sebesar 0,00550

Tujuan Kedua: Pembentukan Keadilan (Iqamah al-'Adl)

Tabel 8. Indikator Kinerja Maqasid al-Shari'ah Tujuan Kedua Periode 2017 - 2020

\begin{tabular}{|c|c|r|}
\hline \multirow{2}{*}{ Bank } & \multicolumn{2}{|c|}{ IK untuk Tujuan kedua (2015-2018) } \\
\cline { 2 - 3 } & IK & TOTAL2 \\
& 22 & 0,04062 \\
\hline BSM & 0,04062 & 0,04636 \\
\hline BRIS & 0,04636 & 0,02945 \\
\hline BNIS & 0,02945 & 0,01629 \\
\hline BJBS
\end{tabular}

Dapat diketahui bahwa secara keseluruhan Bnak BRI Syariah (BRIS) lebih baik dalam mencapai tujuan kedua(pembentukan keadilan) dibandingkan dengan banksyariah lainnya. Keunggulan BRIS dalam mencapai tujuan kedua disebabkan oleh tingginya investasi dengan sistem bagi hasil yang disalurkan oleh BRIS selamaperiode 2017 - 2020, Yang artinya BRIS merupakan bank syariah yang pada tahun 2017 hingga 2020 paling fokus dalam hal rasio pembiayaan mudharabah atau musyarakah.

\section{Tujuan Ketiga: Kepentingan Publik (Jalb al-Maslahah)}

Tabel 9. Indikator Kinerja Maqasid al-Shari’ah Tujuan Ketiga Periode 2017 - 2020

\begin{tabular}{|c|c|c|c|c|c|}
\hline \multirow{2}{*}{ Negara } & \multirow{2}{*}{ Bank } & \multicolumn{4}{|c|}{ IK untuk tujuan ketiga (2015-2018) } \\
\hline & & IK 13 & IK23 & IK33 & TOTAL3 \\
\hline \multirow{4}{*}{ Indonesia } & BSM & 0,00044 & 0,00003 & 0,10232 & 0,10280 \\
\hline & $\overline{\text { BRIS }}$ & 0,00041 & 0,00002 & 0,10027 & 0,10070 \\
\hline & BNIS & 0,00093 & 0,05216 & 0,10335 & 0,15644 \\
\hline & BJBS & $-0,00244$ & 0,00299 & 0,09613 & 0,09669 \\
\hline \multirow{4}{*}{ Malaysia } & BIMB & 0,00093 & 0,00002 & 0,10912 & 0,11006 \\
\hline & BMMB & 0,00056 & 0,00002 & 0,10935 & 0,10993 \\
\hline & BAIBB & 0,00054 & 0,00002 & 0,10799 & 0,10855 \\
\hline & CIMB IBB & 0,00076 & 0,00000 & 0,10783 & 0,10859 \\
\hline \multirow{4}{*}{ Iran } & Parsian bank & 0,00017 & 0,00000 & 0,00151 & 0,00169 \\
\hline & $\begin{array}{c}\text { Kafarin } \\
\text { bank }\end{array}$ & 0,00106 & 0,00000 & 0,00449 & 0,00556 \\
\hline & Tejarat bank & $-0,00109$ & 0,00000 & 0,00084 & $-0,00025$ \\
\hline & Saman bank & 0,00039 & 0,00000 & 0,00668 & 0,00707 \\
\hline
\end{tabular}

Secara umum Bank Negara Indonesia Syariah (BNIS) memperoleh nilai tertinggi dalam 
mencapai tujuan ketiga (kepentingan publik). Hal ini dikarenakan tingginya indikator kinerja zakat dibandingkan dengan bank syariah lainnya selama periode 2017 - 2020.

\subsection{Maqasid Index (MI) Bank Syariah}

Tabel 10. Maqasid Index Bank Syariah Periode 2017 - 2020

\begin{tabular}{|c|c|c|c|c|c|}
\hline Bank & IK(1) & IK(2) & $\mathbf{I K ( 3 )}$ & $\begin{array}{c}\text { MI [IK (T1) + IK } \\
\text { (T2) + IK } \\
\text { (T3) } \\
\text { (SMI) }\end{array}$ & PERINGKAT \\
\hline BSM & 0,00238 & 0,04062 & 0,10280 & 0,14580 & 3 \\
\hline BRIS & 0,00173 & 0,04636 & 0,10070 & 0,14879 & 2 \\
\hline BNIS & $\mathbf{0 , 0 0 5 5 0}$ & 0,02945 & $\mathbf{0 , 1 5 6 4 4}$ & $\mathbf{0 , 1 9 1 3 8}$ & 1 \\
\hline BJBS & 0,00335 & 0,01629 & 0,09669 & 0,11633 & 4 \\
\hline
\end{tabular}

Dalam teori Maqashid Syariah yang dikemukakan oleh Abu Zahra ini terbagi menjadi 3 elemen yang pertama penyucian jiwa atau Pendidikan yang mana membersihkan jiwa dari keburukan keburukan yang melekat, yang kedua keadilan yang mana tidak membedakan antara yang miskin dan yang kaya dan yang ketiga atau yang terakhir adalah kemaslahatan bagi umat, yang akhirnya teori tersebut di adopsi oleh oleh Mohammed et al, (2008) ke dalam dimensi atau karakteristik dan akhirnya menjadi elemen yang dapat diukur secara kuantitatif, yang mana pengukuran tersebut melalui wawancara dengan 16 pakar syariah di Asia dan Timur Tengah.

Dari tabel 11 di atas dapat terlihat bahwa pencapaian tujuan pertama yaitu Pendidikan individu dan tujuan ketiga yaitu kepentingan publik dilakukan paling baik oleh Bank Negara Indonesia Syariah (BNIS) asal Negara Indonesia. Maka dari itu kinerja secara keseluruhan dilihat dari maqasid index, Bank Negara Indonesia Syariah (BNIS) memiliki nilai tertinggi. Hal ini dikarenakan Bank Negara Indonesia Syariah (BNIS) memiliki pencapaian yang cukup bagus di kedua tujuan, tujuan Pendidikan individu maupun tujuan kepentingan publik. Hasil dari penelitian ini pun menarik jika dilihat dari semua perbankan negara Indonesia, hampir menempati pada posisi teratas yang mana negara Indonesia bukanlah negara islam, yang berarti sistem perbankan yang dijalankan oleh perbankan dari Negara Indonesia selalu memperhatikan nilai nilai Maqashid Syariah tidak hanya berfokus pada profit oriented.

\section{Penutup}

Berdasarkan hasil analisis data dan pembahasan dapat ditarik kesimpulan sebagai berikut: Nilai indeks maqasid ( Maqashid Index ) pada perbankan Syariah di Indonesia pada tahun 20172020, mendapati kesimpulan bahwa Bank Negara Indonesia Syariah memiliki nilai tertinggi dikarenakan pencapaian tujuan pertama yaitu Pendidikan individu dan tujuan ketiga yaitu kepentingan public memiliki hasil yang tinggi, Hal ini menunjukkan bahwa pencapaian kinerja perbankan syariah Indonesia baik dari segi maqashid syariah.

Tujuan Pendidikan individu sertakepentingan publikpadaperbankan syariah Indonesia sudah bagus dalam memberikan manfaat yang lebih bagi masyarakat terhadap aktivitas bisnis yang dijalankannya, maka perbankan syariah Indonesia perlu untuk mempertahankan dan meningkatkannya yang kurang di bidang mewujudkan keadilan karena masih kurang baik bila dibandingkan dengan perbankan syariah Negara Iran. Bagi peneliti selanjutnya, diharapkan untuk menggunakan alat ukur lain dalam mengukur kinerja perbankan yang didasarkan pada konsep maqashid syariah. Atau dapat membandingkan antar alat ukur lainnya yang juga didasarkan pada konsep maqashid syariah. 


\section{Daftar Pustaka}

Abu Zahara, Muhammad. (1997). Usul al-Fiqh. Cairo: Dar al-Fikr al-'Arabi

Antonio et al (2012) An Analysis of Islamic Banking Performance Maqashid Index Implementation in Indonesia and Jordania (Journal of Islamic Finance, Vol. 1 No. 1 (2012) 012 - 029. IIUM Institute of Islamic BankingandFinance ISSN 2289-2117 (O)/ 2289-2109).

Farihah, S. M., \& Setiawan, S. (2020). Determinan Intellectual Capital terhadap Profitabilitas di Bank Syariah: Pengujian Mediasi Kinerja Keuangan dan Kinerja Non Keuangan. Jurnal Samudra Ekonomi dan Bisnis, 11(2), 151-165.

Global Islamic Financial Report (GIFR). (2019). Islamic Finance Country Index - IFCI 2019. Islamic Financial Policy.

Imansari, Anisa Dyah. (2015). Analisis Perbandingan Kinerja Perbankan Syariah Berdasarkan Konsep Al- Maqashid Al- Syariah di Indonesia dan Malaysia. Fakultas Ekonomi dan Bisnis Universitas Diponegoro.

Ihsan, Dwi Nur'aini. (2013). Analisis Laporan Keuangan Perbankan Syariah. Jakarta: UIN Jakarta press.

IFSB (Islamic Financial Services Board). (2019). Islamic Financial Service Industry Stability Report IFSB (Islamic Financial Services Board).

Lestari, H. T., Setiawan, S., \& Tripuspitorini, F. A. (2020). Risk Profile, Good Corporate Governance, Earning, dan Capital dalam Memprediksi Financial Distress pada Bank Umum Syariah di Indonesia. JAE (Jurnal Akuntansi dan Ekonomi), 5(2), 100-111.

Mohammed, Mustafa Omar. (2008). The Performance Measures of Islamic Banking Based on the Maqasid Framework. IIUM International Accounting Conference (INTAC IV).

Mohammed, Mustafa Omar dan Fauziah Md Taib. (2015). Developing Islamic Banking Performance Measures Based on Maqasid Al-Shari'ah Framework: Cases of 24 Selected Banks. Journal of Islamic Monetary Economics and Finance.

Mokni, Rim Ben Selma. (2014). Assessing the Bank Profitability in the MENAregion: AComparative Analysis between Conventional and Islamic Bank. International Journal of Islamic and Middle Eastern Finance and Management, vol. 7, no. 3.

Mutia. (2017). Pendekatan Maqashid Shariah Index sebagai Pengukuran Kinerja Perbankan Syariah di Asia Tenggara (Maqashid sharia index approach as performance measurement of sharia banking southeast Asia).

Reza, Ali. (2010). Perbandingan Kondisi Perbankan Syariab di Republik Islam Iran dan Indonesia. Fakultas Syariah dan Hukum UIN Jakarta.

Roza, Ida. (2015). Analisis Perbandingan Kinerja Perbankan Syariah dengan Metode Indeks Maqasid Syariah dan CAMEL. Skripsi UIN Sunan Kalijaga. Yogyakarta.

Setiawan, S., Wulansari, P., \& Dewi, R. P. K. (2020). Pengukuran Tingkat Kinerja Keuangan Dan Kinerja Non Keuangan Pada Bank Syariah Di Lima Negara Asia (Studi Kasus Pada Bank Syariah Dengan Aset Tertinggi). Dinamika Akuntansi Keuangan dan Perbankan, 9(1), 69-78.

Setiawan, I. (2017). Peran Perbankan Syariah Terhadap Perekonomian Di Indonesia (Pendekatan Model VAR/VECM). TEDC Vol. 11 No. 2 MEI 2017, 173.

Teguh, Muhammad. (2014). Metode Kuantitatif untuk Analisis Ekonomi dan Bisnis. Jakarta : Rajawali Press.

Wibowo, Susanto. (2015). Analisis Perbandingan Kinerja Keuangan Perbankan Syariah dengan Metode CAMEL di ASEAN (Studi Komparatif: Indonesia, Malaysia, Thailand). Jurnal Riset Ekonomidan Manajemen, vol. 15, no. 1. 